\title{
Gametogenesis, spawning behavior and larval abundance of the Pacific oyster Crassostrea gigas in the Thau lagoon: Evidence of an environment-dependent strategy
}

\author{
Ubertini Martin ${ }^{1,{ }^{*}}$, Lagarde Franck, Mortreux Serge ${ }^{1}$, Le Gall Patrik ${ }^{1}$, Chiantella Claude ${ }^{1}$, \\ Fiandrino Annie ${ }^{1}$, Bernard Ismael ${ }^{2}$, Pouvreau Stephane ${ }^{3}$, Roque D'Orbcastel Emmanuelle ${ }^{1}$
}

${ }^{1}$ Ifremer/UMR MARBEC, 34200 Sète, France

${ }^{2}$ Eureka Modélisation, 22740 Lézardrieux, France

${ }^{3}$ Ifremer/UMR LEMAR, 29280 Plouzané, France

*Corresponding author : Martin Ubertini, email address : martin ubertini@hotmail.com

\begin{abstract}
:
The Thau lagoon, located at the South of France, provides $10 \%$ of the French pacific oyster Crassostrea gigas production. Despite this intensive shellfish production, the larval recruitment of this species within the Thau lagoon is still misunderstood and spat collection remains highly variable; as a consequence, shellfish farmers rely mostly on hatchery"s spat. The present study aimed to describe reproduction features of $\mathrm{C}$. gigas within the Mediterranean, as well as to explore spawning triggers of this species. To achieve this goal, the reproduction cycle from gametogenesis to spawning was followed during two years in several locations within the Mediterranean Thau lagoon. The spawning behavior of C. gigas within the Thau lagoon appeared to be slightly different from the one of the Atlantic Coast, showing several spawning events from June to October. The minimal temperature for massive spawning was $23^{\circ} \mathrm{C}$, which is much higher than temperatures mentioned in the literature for this species. A strong relationship was found between phytoplankton communities and gametogenesis, the latter being improved by a higher diatom/dinoflagellate ratio. Temperature was insufficient alone to explain spawning, highlighting other potential triggers such as the moon or lightning strikes. We made the hypothesis of a hierarchy of events triggering spawning, encompassing locking, synchrony and intensifying triggers.
\end{abstract}

\section{Statement of relevance}

This paper is filling in a gap in the literature regarding to reproduction of C. gigas in the Thau lagoon, which is always associated to temperature. However, temperature may not be the only factor involved in oyster reproduction, that is what we tried to show in this paper. 


\section{Highlights}

- The reproduction features of Crassostrea gigas were assessed for the first time in a non-tidal Mediterranean lagoon. Phytoplankton concentration and assemblages affected gametogenesis, diatoms having a positive effect. No spawning event was observed below $22^{\circ} \mathrm{C}$, and $23^{\circ} \mathrm{C}$ appeared as a critical temperature for significant spawning events. Full and dark moon in combination with high temperature did enhance spawning events. A hierarchy of spawning triggers was established, which can help shellfish farmers to better forecast spawning events.

Keywords : Mollusc physiology, Spawning triggers, Oysters 


\section{Introduction}

The aquaculture of the oyster Crassostrea gigas in France is largely based on natural recruitment of the species on spat collectors along the Atlantic coast, the remaining spat being provided by hatcheries and nurseries (Pernet et al. 2012). On the French Mediterranean coast, despite the absence of foreshore, natural $C$. gigas spat collection seems possible, particularly in the Thau lagoon (Rayssac et al. 2012). However, in the current state of knowledge, the temporal variability of the natural recruitment within this lagoon did not allow the local shellfish farmers to rely on Thau native spat until now. Massive mortality outbreaks in C. gigas oysters were reported in France, Ireland and the Channel Islands since 2008, resulting in a shortage of supplies of the shellfish (Schikorski et al., 2011). In this context, the understanding of the C. gigas reproduction within the Thau lagoon is of critical importance to fit professional needs.

The pacific oyster $C$. gigas reproduction has been well studied on the Atlantic coast, fitting hatchery, oyster culture and ecology needs. Since 2008, a national monitoring network that aims to observe the reproductive status of the Pacific oyster over a wide geographic range (see http://www.ifremer.fr/velyger, Pouvreau et al., 2016) helps to understand the spatio-temporal variability in the reproductive performance of this species along the Atlantic coast. On the contrary, the combination of environmental factors involved in oyster reproduction in the Mediterranean is poorly documented. The Mediterranean Thau Lagoon is an important European oyster farming area, representing $9.5 \%$ of the French annual production (Robert 2013). This ecosystem is characterized by specific features compared to Atlantic systems: absence of tidal amplitude (oysters are always immerged), higher summer sea water temperatures and salinities (often above $26^{\circ} \mathrm{C}$ and 36 PSU) and lower phytoplankton concentration enriched in small pico-eucaryotes. In this system, growth rates appear to be among the highest in France (Gangnery et al. 2003), but reproductive performances remain unknown.

It has been long known (e.g. Mann, 1979) that gametogenesis of C. gigas depends on temperature and can be partially formalized through the simple concept of "day-degree". In addition, Auby et Maurer (2004), Fabioux et al., (2005) and Enríquez-Díaz et al. (2009) have demonstrated, in laboratory but also at field, that phytoplankton abundance also plays a key-role, especially to fuel fecundity. Nowadays, several generations of deterministic models on C. gigas explain in detail and trough a quantitative way these environment-driven reproductive processes with the help of ecophysiological and bioenergetic approaches (e.g. Pouvreau et al. 2006, Bernard et al. 2011, Thomas et al. 2016) $\square$.

After gametogenesis, spawning of Pacific oysters is also dependent on environmental drivers. In natural conditions, if spawning trigger mechanisms remain largely unclear for temperate 
bivalves (Fournier et al. 2012), it is now admitted that temperature appears as the main cue to trigger $C$. gigas spawning (Dutertre et al. 2009) $\square$, this parameter being widely used in hatcheries. It acts as a threshold: spawning in $C$. gigas does not occur below a daily seawater temperature of 17$18^{\circ} \mathrm{C}$ (Chávez-Villalba et al., 2001, Cognie et al. 2006, Castaños et al. 2009). The Thau lagoon presents particular conditions compared to the colder Atlantic ecosystems since this thermal threshold is reached for over 5 months (from May to September), making this parameter insufficient in itself to explain $C$. gigas spawning.

Apart from temperature effect, several hypotheses are put forward to explain the triggering of spawning within marine molluscs. Phytoplankton blooms can provoke spawning within marine invertebrate species (Himmelman 1975). Pouvreau et al. (2001a, 2001b) and more recently Fournier et al. (2012) showed that the black lip pearl oyster Pinctada margaritifera spawning is significantly related to plankton concentration in the water column, the latter acting as a synchronizing factor. Aranda et al. (2014) $\square$ related maturity and spawning stages to total chlorophyll levels within the species $C$. virginica. The lunar cycle is also supposed to have an influence on spawning synchrony, as it has been demonstrated for corals (Boch et al. 2011) and fishes (Taylor 1984, Takemura et al. 2004). The brightness of lunar light as well as gravitational changes, with maximum gravitational pull occurring when the Moon and Sun are aligned (at periods of new and full moons) may be perceived by animals (Grant et al. 2009). Besides, during the first half of the twentieth century, research was conducted on the possible relationship between the lunar cycle and spawning events within oyster species. Schaefer (1937), but also Loosanoff \& Nomejko (1951) $\square$ found no relationship between spawning events and lunar cycle within the species C. gigas and C. virginica. Working on Ostrea edulis, Korringa (1947) found that brooding starts at the spring tides, occurring 2 days after full and new moon. More recently, Tran et al. (2011) suggested that biological rhythms of $C$. gigas should vary according to the relative importance of the solar cycle and different lunar cycles associated with tide generation. Thanks to a dual approach (specific experiments at field and long term data analysis), Bernard et al. (2016) have demonstrated a relationship between lunar cycle and the spawning events of $C$. gigas working on several sites on the Atlantic coast (MarennesOléron and Arcachon). Lastly, punctual events can also trigger spawning. Working on Haliotis diversicolor, Onitsuka et al. (2007) established a relationship between spawning occurrences and typhoon events in the Sagami Bay (Japan). They hypothesized that those events could be an advantageous phenomenon enhancing larval dispersion in the water column.

In addition to the environmental potential spawning triggers, oysters may have different behaviors in relation to environmental conditions. For example, Aranda et al. (2014) identified two strategies in the spawning behavior of C. virginica: (1) seasonal and synchronous, and (2) continuous and asynchronous. They hypothesized that the first strategy occurs when food 
availability is regular, which could be considered as a "conservative tactic". The second strategy would occur when food availability is irregular; oysters then behave according to an "opportunistic tactic". Considering the ability of oysters to adapt their spawning behavior to environmental conditions (Aranda et al., 2014, Philippart et al., 2014, Jönsson, 1997) is, in our opinion, fundamental to better understand the different reproduction strategies of $C$. gigas according to the environment they live in. We think that spawning triggers, instead of being considered individually, should probably be considered together, interacting simultaneously or according to a not obvious hierarchy. The reproduction cycle of $C$. gigas in shellfish ecosystems is truly complex, and needs to be assessed through global approaches, relating the oyster biology to environmental variables in order to apprehend the hierarchy of factors influencing gametogenesis, spawning behavior and subsequent larval abundance in the water column.

In that context, the present study aimed to: (1) acquire some knowledge concerning the reproduction cycle of $C$. gigas within the Thau lagoon, (2) understand $C$. gigas spawning triggers within the Mediterranean. To achieve this goal, temperature, phytoplankton and reproductive features from gametogenesis to spawning and larval abundances were followed during 2 years at 2 locations at a weekly temporal resolution within the Thau lagoon.

\section{Material and Methods}

\subsection{Study site}

The Mediterranean Thau lagoon is the largest among the multiple lagoons located in the south of France. This stretch of water is $19 \mathrm{~km}$ long, $4.5 \mathrm{~km}$ wide and $5 \mathrm{~m}$ deep on average (Fig. 1). The Thau watershed extends over about $280 \mathrm{~km}^{2}$ and is drained by numerous little streams (3-13 $\mathrm{km}$ ) with intermittent flows (Plus et al. 2006) $\square$. Shellfish are cultivated in 3 areas of the lagoon, namely "Bouzigues", "Mèze" and "Marseillan" from North-East to South-West, the total cultivated area covering about $20 \%$ of the total lagoon's surface; $90 \%$ of the regional shellfish production comes from these areas. The lagoon is almost closed, with only narrow connections to the Mediterranean Sea through the Sète channel and other small connections that are negligible in terms of water exchange (Plus et al. 2006) $\square$. Because of the weak tidal range, the residence time of water masses in the Thau lagoon mainly depends on wind and barometric effects and it has been estimated that the water renewal time is about 3 months.

Within the Thau lagoon, oyster/larvae related collection and analyses were performed in the 3 sites of "Bouzigues", "Mèze" and "Marseillan", while environmental variables were recorded 
from the two extreme sites "Bouzigues" and "Marseillan" from North-East to South-West.

\subsection{Hydro-climatic parameters monitoring}

Wind data (orientation and intensity) as well as atmospheric pressure were acquired through a weather station placed on the Marseillan point. For both Marseillan and Bouzigues stations, temperature was recorded every 10 minutes using an autonomous CTD multiparameter recorder (NKE instrumentation, Hennebont, France) at a $1.5 \mathrm{~m}$ depth. Thunderstorms were recorded at the station and lightning strikes over the Thau lagoon were checked using the "meteo60" database (C) www.meteo60.fr).

\subsection{Sample collection and analyses}

In early March, 18 months-old oysters coming from Marennes-Oléron were transferred to Thau. These oysters were deployed at the 3 sites (Marseillan, Mèze and Bouzigues) in oyster bags at a depth of $1.5 \mathrm{~m}$, inside oyster rearing areas. At a monthly (spring and autumn) and weekly (summer) frequency, 45 individuals were sampled per station. The first 30 individuals were used for biometric measurements as described by Pernet et al. (2012). Total, tissue and shell wet weight were measured as well as shell length. Tissues and shells for dry weight measurements were placed in pre-weighed aluminium cups, dried for $72 \mathrm{~h}$ at $60{ }^{\circ} \mathrm{C}$ and weighed on a Mettler precision balance (Mettler-Toledo, Viroflay, France). Then, Condition Index (CI) was calculated according to Lawrence and Scott, 1982, as follows:

$$
\mathrm{CI}=\text { Dry tissue weight } / \text { (Total wet weight }- \text { Dry shell weight })
$$

The remaining 15 individuals were used to precisely define the stages of sexual maturity by quantitative histology (2012: 644 ind., 2013: 942 ind.). A pool (sampling station/date) of whole oyster flesh was stored in a Davidson fixing medium at $4^{\circ} \mathrm{C}$ until sagittal sections - about $3 \mathrm{~mm}$ thick - were made in front of the pericardial cavity. Each individual, placed in a single incremental plastic box was then dehydrated in successive ethanol baths of increasing concentration before being included in liquid paraffin. The trays were placed in the refrigerator for solidification. The blocks obtained were placed on a manual microtome (Leica RM 2115 RT, Nussloch, Germany) to obtain $5 \mu \mathrm{m}$ cuts, which were deposited on glass slides. They were dried in an oven at $37^{\circ} \mathrm{C}$ for 12 hours. A manual staining of the slides was used in this study by the use of Harris hematoxylin and eosin, a widely used method allowing distinct appearance of the main tissues. After assembly of the slides with a slide glued with resin, each slide was observed under an optical microscope (Zeiss Axioskop - 10 to $100 \mathrm{x}$, LLC, United States) to determine the gametogenesis stage according to the scale described by Chávez Villalba (2001). To determine the gonado-somatic ratio; the slides were 
scanned (HP Pro 750V Scanner) and the resulting image processed using Imaq Vision Builder software (v6.0, National Instrument). Total area of the visceral mass and gonadal area was obtained by manually drawing their contour. The ratio between both areas gives the Gonado-Somatic Index (GSI).

Concerning larval abundance, we applied the standard method used by the French Larval Monitoring Network (VELYGER, Pouvreau et al., 2016). To summarize, $1.5 \mathrm{~m}^{3}$ of seawater was pumped and filtered, twice a week from late May to mid-September with the help of a conic plankton net (mesh size $40 \mu \mathrm{m}$ ). Material retained into the net was conserved in 1 liter sea water bottles (to which were added $10 \mathrm{ml}$ of a $99 \%$ alcohol solution). At laboratory and within $48 \mathrm{~h}$ after sampling, each sample was observed under binocular microscope. C. gigas larvae were identified, counted and classified into four classes according to their developmental stage: small (1-6 days, $<110 \mu \mathrm{m})$, small evolved (6-11 days, 110-190 $\mu \mathrm{m})$, medium (11-16 days, 190-250 $\mu \mathrm{m})$, large (16-20 days, $>250 \mu \mathrm{m})$. We considered significant larval cohorts when the latter classes reached 10000 ind. $\mathrm{m}^{-3}$ in the water column.

Phytoplankton concentrations (cell. $\mathrm{L}^{-1}$ ) were measured by Ifremer's Phytoplankton and Phycotoxin Monitoring Network (REPHY, 2013) at Marseillan and Bouzigues, inside the bivalve farming area, at a depth of $1.5 \mathrm{~m}$. Samples for phytoplankton identification were preserved with Lugol's solution $\left(1 \mathrm{~mL} \cdot \mathrm{L}^{-1}\right)$. Ten milliliters were placed in a phytoplankton chamber for at least $6 \mathrm{~h}$ for sedimentation, then identified and counted using an inverted microscope (Olympus IMT 2, Olympus, Japan), at 40x. Most species were aggregated at their genus level. Water samples were collected at Bouzigues and Marseillan from March to September in 2012 and 2013, at a bimonthly or weekly frequency. About $5 \mathrm{~L}$ of water was collected and pre-filtered through a $200 \mu \mathrm{m}$ screen to remove any large zooplankton or algal debris. Chl $a$ was extracted from 50mL of seawater filtered on Whatman GF/F filters in acetone $90 \%$ for $24 \mathrm{~h}$ in the dark, and its concentration was determined using a Perkin-Elmer spectrofluorometer LS50B (Neveux \& Lantoine 1993) $\square$.

\subsection{Statistical analyses}

Phytoplankton specie biovolumes were found in the literature for Thau species (Dupuy et al. 2000) or calculated at the lab following the equations given by Vadrucci et al. (2013). Nonmultidimensional scaling (nMDS), based on Bray-Curtis dissimilarity using the R package "vegan" were used to highlight the relationships between stations sampled and phytoplankton communities in terms of biovolumes. A SIMPER (Similarity Percentage) analysis using the R package "vegan" was completed to assess which taxa was primarily responsible for the observed difference between groups of samples. 
To characterize the relationships between reproductive activity of $C$. gigas and phytoplankton concentration, we used a Pearson correlation analysis between the absolute variation of GSI and the running mean of phytoplankton concentration, similarly to a technique used by Fournier et al. (2012). The absolute variation of GSI between two sampling dates was calculated using the following equation: $\Delta_{\mathrm{GSI}}=\mathrm{GSI}_{\mathrm{d}}-\mathrm{GSI}_{\mathrm{d}-7}$, where $\Delta_{\mathrm{GSI}}=\mathrm{GSI}$ variation (\%) and $\mathrm{GSI}_{\mathrm{d}}$ is the gonado-somatic index of $C$. gigas at the sampling date $\mathrm{d}$ and at the previous sampling date (7 days before $\mathrm{GSI}_{\mathrm{d}}=\mathrm{GSI}_{\mathrm{d}-7}$ ). Then, we calculated the running mean of phytoplankton concentration for 4 periods of time (7, 15, 21 and 28 days), assuming that GSI variation could be related to the integration of phytoplankton during the week to the month before. This running mean was done for 5 phytoplankton classes: total, $>20 \mu \mathrm{m}$, micro-, nano-, and pico-phytoplankton. Finally, we associated each $\Delta_{\mathrm{GSI}}$ value with the values of running means calculated for the day corresponding to $\mathrm{GSI}_{\mathrm{d}}$ sampling date and we used a Pearson correlation analysis to test the relationships between $\Delta_{\mathrm{GSI}}$ and the 4 running means of phytoplankton concentration.

The effect of the lunar cycle was assessed in relation to larval cohorts. Small larvae in the water column were aged from 1 to 6 days, thus the related spawning window was situated within the 6 previous days. A one-way ANOVA was performed using $\mathrm{R}$ in order to identify the potential effect of the lunar phases on $C$. gigas larvae abundances. The moon was considered as a binary variable, the spawning window being characterized by the presence/absence of a full/new moon. Then exact Fisher tests were performed using $\mathrm{R}$ to determine how spawning events were affected by the moon or by the combination of moon and temperature. Observed distribution of moon-/nomoon related spawning events was compared to a 50/50 theoretical distribution of significant spawning events indicating no relationship at all with the moon.

\section{Results}

\subsection{Environmental factors}

\subsubsection{Climatic context}

As for Atlantic ecosystems with the North Atlantic oscillation, Mediterranean ecosystems can be characterized by a hydroclimatic regime, the Western Mediterranean Oscillation (WeMO, Martin-Vide \& Lopez-Bustins 2006), the index of which was mainly negative for both 2012 and 2013 (Fig. 2). The negative phase of the WeMO coincides with the Central European anticyclone located to the north of the Italian peninsula and a cyclone, often cut off from northern latitudes, in an extensive area comprising the south-western Iberian Peninsula and the surrounding Atlantic 
Ocean. This Mediterranean circulation supplies moist warm air to the southern side of the Eastern Pyrenees (García-Sellés et al. 2010), and is responsible for more precipitations.

During 2012-2013, the Thau lagoon was mainly characterized by strong winds coming from the North-West, and marine winds coming from the South (Fig. 3). Temperatures followed the same patterns at the 3 sampled stations, but there was a gradient of temperature from North-East to South-West, Bouzigues being the coldest station and Marseillan being the hottest station (KruskallWallis, $\mathrm{Khi}^{2}=247.97$, p-value $\left.<0.001\right)$. The year 2012 was characterized by a lower temperature than the year 2013 for spring season (Fig. 3). After a rapid temperature increase in June, the temperatures reached those of 2012. Between the beginning of April and the end of September, respective minimal and maximal temperatures were $11^{\circ} \mathrm{C}$ and $29^{\circ} \mathrm{C}$, the minimal $17^{\circ} \mathrm{C}$ threshold temperature allowing spawning being reached during 5 months for both years. The year 2013 was characterized by more thunderstorms than the year 2012, which appeared more regularly during the reproductive season. This thunderstorm event increase was related to the lower WeMO index in 2013 for the months of July and August.

\subsubsection{Trophic environment}

To characterize trophic resources within the Thau lagoon, the Northern station Bouzigues and the Southern station Marseillan phytoplankton assemblages considered as a function of their biovolumes were computed in a non-Metric Dimensional Scaling (nMDS) analysis (Fig. 4). For both years 2012 and 2013, phytoplankton assemblages were different between both stations. In 2012, phytoplankton species were well distinguished by types, with a pattern dominated by dinoflagellates while the rest of the analysis space was dominated by diatoms. The different samplings realized in the summer showed that most of the Marseillan samplings were characterized by higher dinoflagellates abundances than Bouzigues. In the same way, 2013 was characterized by 2 distinct patterns between dinoflagellate and diatom dominance, with most of the Marseillan samplings being located close to the dinoflagellate pattern. Among the 10 phytoplankton species which contributed the most to the analysis dissimilarities between Bouzigues and Marseillan datasets (Table 1), five species were common to both years 2012 and 2013: Rhizosolenia setigera, Gonyaulax, Peridinium, Thalassionema and Gymnodinium. For both years, the diatom Rhizosolenia setigera was the species that contributed most to the dissimilarity between Bouzigues and Marseillan datasets.

\subsection{Spatio-temporal variability in gametogenesis}

The condition index (CI, \%) was measured on C. gigas in 2012 and 2013, showing different patterns for both years and between stations (Fig. 5). In 2012, CI evolution was asynchronous 
between the 3 sampled stations, with a first peak for Marseillan in mid-May, for Meze at the beginning of June and for Bouzigues at the beginning of July. In 2013, we observed a more synchronized pattern between the 3 stations, with a first increase of the CI from March to the beginning of May followed by a second increase from March to mid-July, and a third peak observed at the end of summer. Gonado-Somatic Index (GSI, \%) was evaluated through histological analysis for each individual during both reproduction seasons (Fig. 6). Gametogenesis started in April for both years, with class 2 stage appearing at the beginning of June in 2012 and at the end of April in 2013. The different stations had the same global evolution pattern regarding the distribution of maturation stages (Fig. 6). However, in 2012, we observed 2 major gonad class regressions at Bouzigues, 1 in Marseillan and 3 in Mèze. In 2013, the 3 stations showed a more synchronized evolution in terms of gametogenesis cycles. We observed multiple gonad maturation events from March to the end of September, indicating asynchronous maturation within oyster groups and/or multiple maturation events. Gametogenesis appears to be possible during the whole summer reproductive season in this ecosystem, with spatial variability between sites and a possible rematuration process of the gonad.

\subsection{Larval abundance}

During the 2 reproduction seasons, larvae at various developmental stages were observed from the beginning of June to the end of September (Fig. 7). All stages were present through the reproduction season, showing a complete development of the $C$. gigas pelagic larvae in the lagoon for both years. During that 4-months period, multiple peaks of small larvae were observed for both years 2012 and 2013, indicating multiple spawning events in the 3 sectors during summer. Altogether, we observed respectively a total of 14 significant pics of small larvae (1-6 days-old) in the water column $\left(>10000\right.$ ind. $\left.\mathrm{m}^{-3}\right)$. First spawning events appeared at the end of Spring for both years 2012 and 2013, with small larvae observed on the $21^{\text {th }}$ of June 2012 at Marseillan (27466 ind. $\mathrm{m}^{-3}$ ) and on the $17^{\text {th }}$ of June 2013 at Mèze (12333 ind. $\left.\mathrm{m}^{-3}\right)$. The highest small larvae abundances were observed on the $5^{\text {th }}$ of July 2012 at Mèze (414633 ind. ${ }^{-3}$ ) and on the $22^{\text {th }}$ of July 2013 at Bouzigues (169000 ind. $\mathrm{m}^{-3}$ ), even if the abundance of larvae was 4 times lower the second year.

. The last significant larvae peaks were observed on the $8^{\text {th }}$ of August 2012 at Marseillan (11933 ind. $\mathrm{m}^{-3}$ ) and on the $26^{\text {th }}$ of August 2013 also at Marseillan (21933 ind. $\mathrm{m}^{-3}$ ). Larval abundances decreased at each stage (from small to large larvae) in the water column. The loss of larvae from the beginning to the end of their pelagic life is of the order of a factor $\log 2$, determined thanks to a well-identified cohort on the $5^{\text {th }}$ of July 2012. 


\subsection{Environmental spawning triggers}

\subsubsection{Temperature}

The first potential spawning trigger is presumably linked to water temperature. No larval cohorts were observed below $20^{\circ} \mathrm{C}$ (Fig. 8). Even if small cohorts were observed between 20 and $22^{\circ} \mathrm{C}$ at the end of the reproduction season, the first cohorts only appeared at temperatures over $22^{\circ} \mathrm{C}$. The more significant larval cohorts $\left(>10000\right.$ ind. $\left.\mathrm{m}^{-3}\right)$ appeared in the water column when water temperatures reached $23^{\circ} \mathrm{C}$.

\subsubsection{Phytoplankton}

The relationship between phytoplankton concentration and C. gigas spawning was assessed by exploring the potential linkage between $\mathrm{Chl}$ a concentration and GSI fluctuations. Results differed between the 2 years: 2013 was characterized by a significant negative relationship between GSI fluctuations and different $\mathrm{Chl}$ a concentration classes. A good correlation was found for the 2 weeks mean total $\mathrm{Chl}$ a concentration at Bouzigues $(\rho$ spearman $=-0.65$, p-value $<0.01)$ and the 3 weeks mean total $\mathrm{Chl}$ a concentration at Marseillan $(\rho$ Spearman $=-0.67$, p-value $<0.01)$. Thus, in 2013, GSI decreased meanwhile Chl a increased in the water column and conversely. The inverse relationship was found in 2012, with GSI and 3 week mean micro Chl a concentration being positively related at Marseillan ( $\rho_{\text {Spearman }}=0.54$, p-value $\left.<0.05\right)$. GSI and 2 week mean total Chl a concentration were also positively related at Bouzigues $(\rho$ Spearman $=0.56$, p-value $<0.05)$.

\subsubsection{Lunar cycle}

Both full moon and new moon appearance during the spawning window affected the number of larvae in the water column with significant higher larvae abundances (ANOVA, $F=4.783$, $p$ value $=0.030$ ). Among the 28 significant cohorts observed for both years at all stations, 19 larval cohorts were characterized by a full/new moon appearance during the related spawning window. The relationship between significant larval cohort appearance and moon phases was not significant $\left(\chi^{2}, \mathrm{p}\right.$-value $\left.=0.277\right)$.

\subsubsection{Lunar cycle associated to temperature}

The lunar cycle happens whatever the temperature is during the whole year; on the contrary, the temperature appeared to have a critical value of $23^{\circ} \mathrm{C}$ under which we did not observe 
significant spawning. We thus made the hypothesis that a full/new moon could trigger spawning only if temperature was over $23^{\circ} \mathrm{C}$ during the spawning window, and that a spawning window characterized by both full/new moon and a temperature below $23^{\circ} \mathrm{C}$ would lead to a delayed spawning when temperature would increase anew over $23^{\circ} \mathrm{C}$. In order to test our hypothesis, we thus explored the remaining 9 significant spawning events that were not characterized by a full/new moon appearance during the related spawning window. Among them, 6 were in line with our hypothesis, with previous full/dark moon characterized by a temperature under $22^{\circ} \mathrm{C}$. We tested that new condition regrouping moon and moon delayed spawning together, which appeared to be accurate to explain significant spawning $\left(\chi^{2}, \mathrm{p}\right.$-value $\left.=0.003\right)$.

\subsubsection{Thunderstorms}

As for the lunar cycle, lightening impacts on the Thau lagoon were considered as a binary variable, appearing or not during the 6 days preceding a cohort apparition in the water column. Lightning impacts - 14 during the studied period - did significantly affect the number of larvae in the water column (ANOVA, $F=9.553, p$-value $=0.002$ ). When considering only significant spawning events, lightning impacts did have a significant effect on larvae concentration (ANOVA, $\mathrm{F}=7.185, \mathrm{p}=0.012$ ), with more larvae in the water column after a lightning impact within the 6 day potential spawning period.

\section{Discussion}

\subsection{Phytoplankton as a fuel for gametogenesis}

Settlement and recruitment dynamic are known to be largely affected directly by competent larvae supply, transport processes, availability of space and habitat selectivity but also indirectly by adults population, individual gametogenesis, fecundity and spawning strategy (e.g. Rodriguez et al., 1993). One of the Thau lagoon's specificity is the absence or quasi-absence of wild oyster broodstock and reproductive effort relies only on cultivated oysters. From one year to another, cultivated oyster stocks may vary on both (1) quantitative and (2) qualitative ways, since farmers may switch between diploid and triploid-sterile cultures. But, we can make the reasonable hypothesis that stocks of oysters were nearly the same all along the present study. In such context, the gametogenesis step could be of crucial interest to better analyze reproduction success of $C$. gigas in the Thau lagoon. 
Gametogenesis is known to be highly dependent on environmental conditions. For instance, it may suffer from possible (1) trophic limitation at the lagoon scale as well as (2) rapid temporal variations. Biometry revealed that the Bouzigues station allowed a better growth than the Marseillan station, but also a higher reproductive effort. However this reproductive effort is difficult to assess since multiple spawning events happen in the summer. Influence of phytoplankton on gametogenesis has been demonstrated within many oyster species (Pouvreau et al., 2001; Fabioux et al., 2004; Fournier et al. 2012; Aranda et al. 2014). More precisely, Enríquez-Díaz et al. (2009) showed for Crassostrea gigas that if temperature was the main factor driving the gametogenesis rate, food availability was responsible of gametogenesis intensity (fecundity). Our observations are totally in line with these authors, since we observed similar kinetics of gametogenesis between the two studied sites (Marseillan and Bouzigues) but different intensities probably due to differences in terms of phytoplankton communities and abundances. For instance, we observed more diatoms at "Bouzigues" than at "Marseillan", C. gigas being known to feed mainly on diatoms (Dupuy et al. 2000, Pernet et al. 2012). In fact, Rhizosolenia setigera contains 4310 pg C.cell $^{-1}$ (Dupuy et al., 2000), making this species interesting in terms of food supply. That difference in terms of phytoplankton communities between the 2 points must be linked to (1) the confinement gradient of the lagoon (Bernard et al. 2013) $\square$, Bouzigues being more linked to the sea and thus being characterized by a better water renewal and (2) the fact that new water coming from the North-East has already been filtered by oysters. The better growth in 2013 at the Bouzigues station during August and September can be clearly linked to the dominance of large diatoms such as Coscinodiscus, Rhyzosolenia, Thalassionema during these months (Fig.4).

\subsection{An asynchronous spawning strategy}

This study is the first to highlight the reproduction strategy of $C$. gigas in a Mediterranean lagoon. We showed that the reproduction window within the Thau lagoon is stretched from the beginning of June to the end of September, and is characterized by multiple, asynchronous and partial spawning events for both studied years. These results show that gametogenesis and spawning are much more asynchronous in the Thau Lagoon compared with what has been observed on the French Atlantic or Channel coasts (Royer et al. 2008; Enriquez et al., 2009 ; Dutertre et al. 2009) both places being under macrotidal regime. Besides synchronicity, Dutertre et al. (2009) observed during 2005 and 2006 two spawning events per year, between $18^{\circ} \mathrm{C}$ and $22^{\circ} \mathrm{C}$, but Royer et al. (2008), Enriquez et al. (2009) and Bernard et al. (2016) observed only one synchronous spawning event per season. In any case, our observations are different from the previously cited literature, since we observed asynchrony between sites within the same ecosystem as well as within sites. There is little literature concerning $C$. gigas reproduction cycle in non-tidal ecosystems, except the 
study performed by Dridi et al. (2007) in the lagoon of Bizert (Tunisia). Authors show that spawning occurred from June to September at temperatures spreading from $23^{\circ} \mathrm{C}$ to $27^{\circ} \mathrm{C}$, a temperature window and threshold which are rather in accordance with our study. The apparent difference in terms of synchronicity of the reproduction between tidal on non-tidal systems may be related to different hypothesis: (1) In tidal ecosystems, synchronicity of the reproduction is all the more important that gametes are washed away during ebb-tide, while non-tidal lagoons offer more chances for gamete encountering; (2) Mediterranean lagoons, because of a lower water renewal than tidal systems, are characterized by a more spatially heterogeneous biocoenoses, increasing the spatial heterogeneity of the whole ecosystem and thus the heterogeneity of gonad maturation within the lagoon. Our results, in complement of the review given by Castaños et al. (2009) $\square$ regarding $C$. gigas reproduction, underline the species reproduction plasticity of the Pacific oyster to different kinds of ecosystems.

\subsection{Hierarchy of spawning triggers}

Numerous spawning triggers have been mentioned within marine bivalve species. Among them and for the species Crassostrea gigas, the main trigger seems to be played by the temperature threshold. It is reported in the literature to vary between $17^{\circ} \mathrm{C}$ (Castaños et al. 2009) and $18^{\circ} \mathrm{C}$ (Cognie et al. 2006, Dutertre et al. 2009) among several ecosystems. In the Thau lagoon, for the years 2012 and 2013, we observed that first spawning events occurred at a temperature of $22^{\circ} \mathrm{C}$. This $4-5^{\circ} \mathrm{C}$ difference with the previously cited literature may have two explanations. The likeliest hypothesis is the difference in terms of temperature stress between Atlantic and Mediterranean ecosystems. In fact, during the flow within Atlantic tidal ecosystems in the summer, animals are exposed to a temperature stress resulting of the difference between the warm air and the incoming colder water. On the contrary, within Mediterranean ecosystems, there is no such stress because of the absence of noticeable tidal amplitude. Moreover, the gonad maturation in the Thau lagoon could be insufficient at $17-18^{\circ} \mathrm{C}$ to ensure internal triggering of spawning processes. In fact, the greatest number of mature individuals corresponded to the first appearance of significant larval cohorts. The latter was observed in the water column at a temperature exceeding $23^{\circ} \mathrm{C}$, optimal temperature for larvae development being superior to $22^{\circ} \mathrm{C}$ (Rico-Villa et al., 2009). Thus, once the gonad maturity is reached, temperature must be - as for many other ecosystems - an important trigger for gamete release. However, reproduction within the Thau lagoon is characterized by multiple spawning events during the wide favorable temperature window, making the temperature itself insufficient to explain accurately spawning strategy in this ecosystem.

Once conditions are met to release gametes in the water column, oysters need to rely on synchrony for increasing the gamete matching chances. We used the same analysis as Fournier et al. 
(2012) for Pinctada margaritifera in order to identify the potential effect of phytoplankton concentration as a spawning trigger for the $C$. gigas species. While they identified it for the species P. margaritifera, we were not able to identify it for $C$. gigas, at least not for both years, as they showed opposite results.

The moon influence on marine species spawning has been widely studied, especially for corals (Nozawa 2012). Moon influence on spawning events within the species Ostrea virginica has been well studied by Loosanoff \& Nomejko (1951) $\square$, who found no clear relationship between moon phases and spawning. More recently, Tran et al. (2011) and Bernard et al. (2016) found a strong relationship between the rhythms of valve behavior - related to gamete release - and the association of the sun-earth-moon orbital positions. The extremely moderated neap-spring tide cycle $(\sim 40 \mathrm{~cm})$ associated to the permanent immersion of followed individuals allowed us to highlight the moon influence as a synchrony trigger for gamete release within the Thau lagoon. In our study, among the 28 significant cohorts observed for both years at all stations, 19 larval cohorts were characterized by a full/new moon appearance during the related spawning window. Further investigations about this result should deserve a particular attention.

In addition to major triggers affecting presence/absence and synchrony of spawning events, punctual additional triggers may add a degree of complexity to the $C$. gigas spawning strategy. The punctual nature of these events makes them difficult to analyze and they are thus poorly documented, whereas local farmers often consider them as determinant environmental factors. Localized thunderstorms, typical during the summer over the Thau lagoon, could be potential punctual spawning triggers. They notably affected the number of larvae in the water column even when considering only significant spawning events, and the largest small larvae cohorts in the water for both years 2012 and 2013 were preceded by a thunderstorm in the 5 previous days (Table 3 ). Even if they may have confounded effects with moon and/or temperature, thunderstorms could be additional signals triggering spawning events.

\section{Conclusion}

Understanding the whole reproductive cycle from gametogenesis of adults to settlement of progeny has always represented a challenging issue in marine invertebrates. Of course, environmental driving variables are numerous and may be different from one ecosystem to another. In that context, our study aimed to give some answers within the species $C$. gigas and in a particular the Mediterranean lagoon where $C$. gigas has been introduced artificially for shellfish purposes. It appears from our study that the reproduction window within the Thau lagoon stretches from the beginning of June to the end of September, and is characterized by multiple, asynchronous and 
partial spawning events. From a quantitative point of view, gametogenesis intensity (GSI, fecundity) was correlated to the abundance of diatoms. Once gametogenesis is complete, spawning can occur according to 3 types of spawning triggers: (1) temperature should be considered as a "locking trigger" with a threshold value above $22^{\circ} \mathrm{C}$; (2) the moon (full and new) appeared as a "synchrony trigger" maximizing chances of gamete matching; (3) a last additional trigger like thunderstorms may increase the gamete release, acting more like a stressful trigger. These new findings should play one's part in the conceptual pattern of the $C$. gigas reproduction in non-tidal Mediterranean.

\section{Acknowledgements}

We would like to thank France-Agrimer, Conseil Régional d'Occitanie/LanguedocRoussillon, Conseil départemental de l'Hérault, Comité Régional de la Conchyliculture en Méditerranée, Cepralmar and Ifremer for their financial support in the scientific part of PRONAMED 2 project (2012-2015). This work was made possible thanks to the collaboration of the LERLR team and special thanks go to Hélène Cochet, Béatrice Bec, Marie Boj, Axel Leurion and Solenn Soriano for their availability for the 2012 and 2013 campaigns. The authors are also grateful to the Ifremer staff of the RESCO, VELYGER and REPHY networks, through which parts of the field data were gathered. Finally, we would like to thank the 3 reviewers who helped us a lot in improving the quality of this article. 


\section{References}

Aranda DA, Díaz ME, Reynoso FL, Brulé T, Montero J, Cárdenas EB (2014) Reproductive Strategies of the Eastern Oyster Crassostrea virginica (Gmelin 1791) in Tropical Lagoons of the Mexican Gulf of Mexico. J Shellfish Res 33:145-152

Auby I, Maurer D (2004) Etude de la reproduction de l'huître creuse dans le Bassin d'Arcachon. http://archimer.ifremer.fr/doc/00040/15145/

Bernard J-P, Frenod E, Rousseau A (2013) Modeling confinement in Etang de Thau: numerical simulations and multi-scale aspects. Dyn Syst Differ Equations, DCDS Suppl 2013:69-76

Bernard I, Kermoysan G de, Pouvreau S (2011) Effect of phytoplankton and temperature on the reproduction of the Pacific oyster Crassostrea gigas: Investigation through DEB theory. J Sea Res 66:349-360

Bernard, I. et al. In situ spawning in a marine broadcast spawner, the Pacific oyster Crassostrea gigas: Timing and environmental triggers. Limnol. Oceanogr. 61, 635-647 (2016).

Boch C a., Ananthasubramaniam B, Sweeney AM, Doyle FJ, Morse DE (2011) Effects of light dynamics on coral spawning synchrony. Biol Bull 220:161-173

Castaños C, Pascual M, Camacho AP (2009) Reproductive Biology of the Nonnative Oyster, Crassostrea gigas (Thunberg, 1793), as a Key Factor for Its Successful Spread Along the Rocky Shores of Northern Patagonia, Argentina. J Shellfish Res 28:837-847

Chávez-Villalba JE (2001). Conditionnement expérimental de l'huître Crassostrea gigas. PhD thesis. University of Bretagne Occidentale, France

Chávez-Villalba J., Mingant C., Cochard J.C., Le Pennec M., 2001, Gamétogenèse chez l'hui $\square$ tre Crassostrea gigas de l'Aber Benoi $\square \mathrm{t}$ (Bretagne, France), à la limite nord de son aire de reproduction. Haliotis 30, 1-12.

Cognie B, Haure J, Barillé L (2006) Spatial distribution in a temperate coastal ecosystem of the wild stock of the farmed oyster Crassostrea gigas (Thunberg). Aquaculture 259:249 259

Dridi S, Romdhane MS, Elcafsi M (2007) Seasonal variation in weight and biochemical 
composition of the Pacific oyster, Crassostrea gigas in relation to the gametogenic cycle and environmental conditions of the Bizert lagoon, Tunisia. Aquaculture 263:238-248

Dupuy C, Vaquer a., Lam-Hoai T, Rougier C, Mazouni N, Lautier J, Collos Y, Gall S Le (2000) Feeding rate of the oyster Crassostrea gigas in a natural planktonic community of the Mediterranean Thau Lagoon. Mar Ecol Prog Ser 205:171-184

Dutertre M, Beninger PG, Barillé L, Papin M, Rosa P, Barillé A-L, Haure J (2009) Temperature and seston quantity and quality effects on field reproduction of farmed oysters, Crassostrea gigas , in Bourgneuf Bay, France. Aquat Living Resour 22:319-329

Enríquez-Díaz M, Pouvreau S, Chávez-Villalba J, Pennec M Le (2009) Gametogenesis, reproductive investment, and spawning behavior of the Pacific giant oyster Crassostrea gigas: Evidence of an environment-dependent strategy. Aquac Int 17:491-506

Fabioux C, Huvet A, Souchu P Le, Pennec M Le, Pouvreau S (2005) Temperature and photoperiod drive Crassostrea gigas reproductive internal clock. Aquaculture 250:458470

Fournier J, Levesque E, Pouvreau S, Pennec M Le, Moullac G Le (2012) Influence of plankton concentration on gametogenesis and spawning of the black lip pearl oyster Pinctada margaritifera in Ahe atoll lagoon (Tuamotu archipelago, French polynesia). Mar Pollut Bull 65:463-470

Gangnery A, Chabirand JM, Lagarde F, Gall P Le, Oheix J, Bacher C, Buestel D (2003) Growth model of the Pacific oyster, Crassostrea gigas, cultured in Thau Lagoon (Méditerranée, France). Aquaculture 215:267-290

García-Sellés C, Peña JC, Martí G, Oller P, Martínez P (2010) WeMOI and NAOi influence on major avalanche activity in the Eastern Pyrenees. Cold Reg Sci Technol 64:137-145

Grant R, Chadwick E, Halliday T (2009) The lunar cycle: a cue for amphibian reproductive phenology? Anim Behav 78:349-357

Himmelman JH (1975) Phytoplankton as a stimulus for spawning in three marine invertebrates. J Exp Mar Bio Ecol 20:199-214

Jönsson K (1997) Capital and Income Breeding as Alternative Tactics of Resource Use in Reproduction. Oikos 78 (1):57-66

Korringa P (1947) Relations between the Moon and Periodicity in the Breeding of Marine Animals. Ecol Monogr 17:347-381 CR - Copyright \&\#169; 1947 Ecological Soc

Lawrence, D. R. \& Scott, G. I. The Determination and Use of Condition Index of Oysters. Estuaries 5, 23-27 (1982).Loosanoff VL, Nomejko CA (1951) Spawning and Setting of the American Oyster, O. Virginica, in Relation to Lunar Phases. Ecology 32:113-134

Mann R (1979) Some biochemical and physiological aspects of growth and gametogenesis in Crassostrea gigas and Ostrea edulis grown at sustained elevated temperatures. J Mar 
Biol Assoc United Kingdom 59:95-110

Martin-Vide J, Lopez-Bustins J-A (2006) The Western Mediterranean Oscillation and rainfall in the Iberian Peninsula. Int J Climatol 26:1455-1475

Neveux J, Lantoine F (1993) Spectrofluorometric assay of chlorophylls and phaeopigments using the least squares approximation technique. Deep Sea Res Part I Oceanogr Res Pap 40:1747-1765

Nozawa Y (2012) Annual variation in the timing of coral spawning in a high-latitude environment: Influence of temperature. Biol Bull 222:192-202

Onitsuka T, Kawamura T, Horii T, Takiguchi N, Takami H, Watanabe Y (2007) Synchronized spawning of abalone Haliotis diversicolor triggered by typhoon events in Sagami Bay, Japan. Mar Ecol Prog Ser 351:129-138

Pernet F, Malet N, Pastoureaud A, Vaquer A, Quéré C, Dubroca L (2012) Marine diatoms sustain growth of bivalves in a Mediterranean lagoon. J Sea Res 68:20-32

Philippart, C,Van Bleijswijk, J, Kromkamp, J, Zuur, A, Herman, P, Reproductive phenology of coastal marine bivalves in a seasonal environment. J. Plankton Res. 36 (6): 1512-1527

Plus M, Jeunesse I La, Bouraoui F, Zaldívar JM, Chapelle A, Lazure P (2006) Modelling water discharges and nitrogen inputs into a Mediterranean lagoon: Impact on the primary production. Ecol Modell 193:69-89

Pouvreau S, Bourles Y, Lefebvre S, Gangnery A, Alunno-Bruscia M (2006) Application of a dynamic energy budget model to the Pacific oyster, Crassostrea gigas, reared under various environmental conditions. J Sea Res 56:156-167

Pouvreau Stephane, Maurer Daniele, Auby Isabelle, Lagarde Franck, Le Gall Patrik, Cochet Hélène, Bouquet Anne-Lise, Geay Amélie, Mille Dominique (2016). VELYGER Database: The Oyster Larvae Monitoring French Project. SEANOE. http://doi.org/10.17882/41888

Pouvreau Stephane, Bacher Cedric, Heral Maurice (2000a). Ecophysiological model of growth and reproduction of the black pearl oyster, Pinctada margaritifera: potential applications for pearl farming in French Polynesia. Aquaculture, 186(1-2), 117-144. Publisher's official version : http://doi.org/10.1016/S0044-8486(99)00373-7, Open Access version : http://archimer.ifremer.fr/doc/00000/380/

Pouvreau Stephane, Gangnery Aline, Tiapari Jerome, Lagarde Franck, Garnier Matthieu, Bodoy Alain (2000b). Gametogenic cycle and reproductive effort of the tropical blacklip pearl oyster, Pinctada margaritifera (Bivalvia : Pteriidae), cultivated in Takapoto atoll (French Polynesia). Aquatic Living Resources, 13(1), 37-48. Publisher's official version : http://doi.org/10.1016/S0990-7440(00)00135-2, Open Access version : http://archimer.ifremer.fr/doc/00000/1391/

Rayssac N, Pérignon A, Gervasoni E, Pernet F, Gall P Le, Lagarde F (2012) Projet 
PRONAMED 2010-2011. Évaluation du potentiel d'approvisionnement naturel en naissains d'huîtres creuses en Méditerranée (Rapport final).

REPHY (2013): Réseau de Surveillance du Phytoplancton et des Phycotoxines. Available online: http://www.ifremer.fr/envlit/surveillance/rephy.htm (accessed 30/11/2016).

Rico-Villa, B., Pouvreau, S. \& Robert, R. Influence of food density and temperature on ingestion, growth and settlement of Pacific oyster larvae, Crassostrea gigas. Aquaculture 287, 395-401 (2009).

Robert R (2013) A glimpse on the mollusc industry in Europe. Aquac Eur:1-12Rodriguez, S.R., Ojeda, F.P., Inestrosa, N.C., 1993. Settlement of benthic marine invertebrates. Mar. Ecol. Prog. Ser. 97, 193-207. doi:10.3354/meps097193

Royer J, Seguineau C, Park K Il, Pouvreau S, Choi KS, Costil K (2008) Gametogenetic cycle and reproductive effort assessed by two methods in 3 age classes of Pacific oysters, Crassostrea gigas, reared in Normandy. Aquaculture 277:313-320

Schaefer MB (1937) Attachment of the Larvae of Ostrea Gigas, the Japanese Oyster, to Plane Surfaces. Ecology 18:523-527

Schikorski D, Renault T, Saulnier D, Faury N, Moreau P, Pépin JF (2011) Experimental infection of Pacific oyster Crassostrea gigas spat by ostreid herpesvirus 1:

Demonstration of oyster spat susceptibility. Veterinary Research 42:27

Takemura A, Rahman MS, Nakamura S, Young JP, Takano K (2004) Lunar cycles and reproductive activity in reef fishes with particular attention to rabbitfishes. Fish Fish $5: 317-328$

Taylor MH (1984) Lunar Synchronization of Fish Reproduction. Trans Am Fish Soc 113:484493

Thomas Y, Dumas F, Andréfouët S (2014) Larval dispersal modeling of pearl oyster Pinctada margaritifera following realistic environmental and biological forcing in ahe atoll lagoon. PLoS One 9

Thomas, Y. et al. Global change and climate-driven invasion of the Pacific oyster (Crassostrea gigas) along European coasts: A bioenergetics modelling approach. J. Biogeogr. 43, 568-579 (2016).

Tran D, Nadau A, Durrieu G, Ciret P, Parisot J-P, Massabuau J-C (2011) Field Chronobiology of a Molluscan Bivalve: How the Moon and Sun Cycles Interact to Drive Oyster Activity Rhythms. Chronobiol Int 28:307-317

Vadrucci MR, Stanca E, Mazziotti C, Umani SF, Georgia A, Moncheva S, Romano A, Bucci R, Ungaro N, Basset A (2013) Ability of phytoplankton trait sensitivity to highlight anthropogenic pressures in Mediterranean lagoons: A size spectra sensitivity index (ISS-phyto). Ecol Indic 34:113-125 


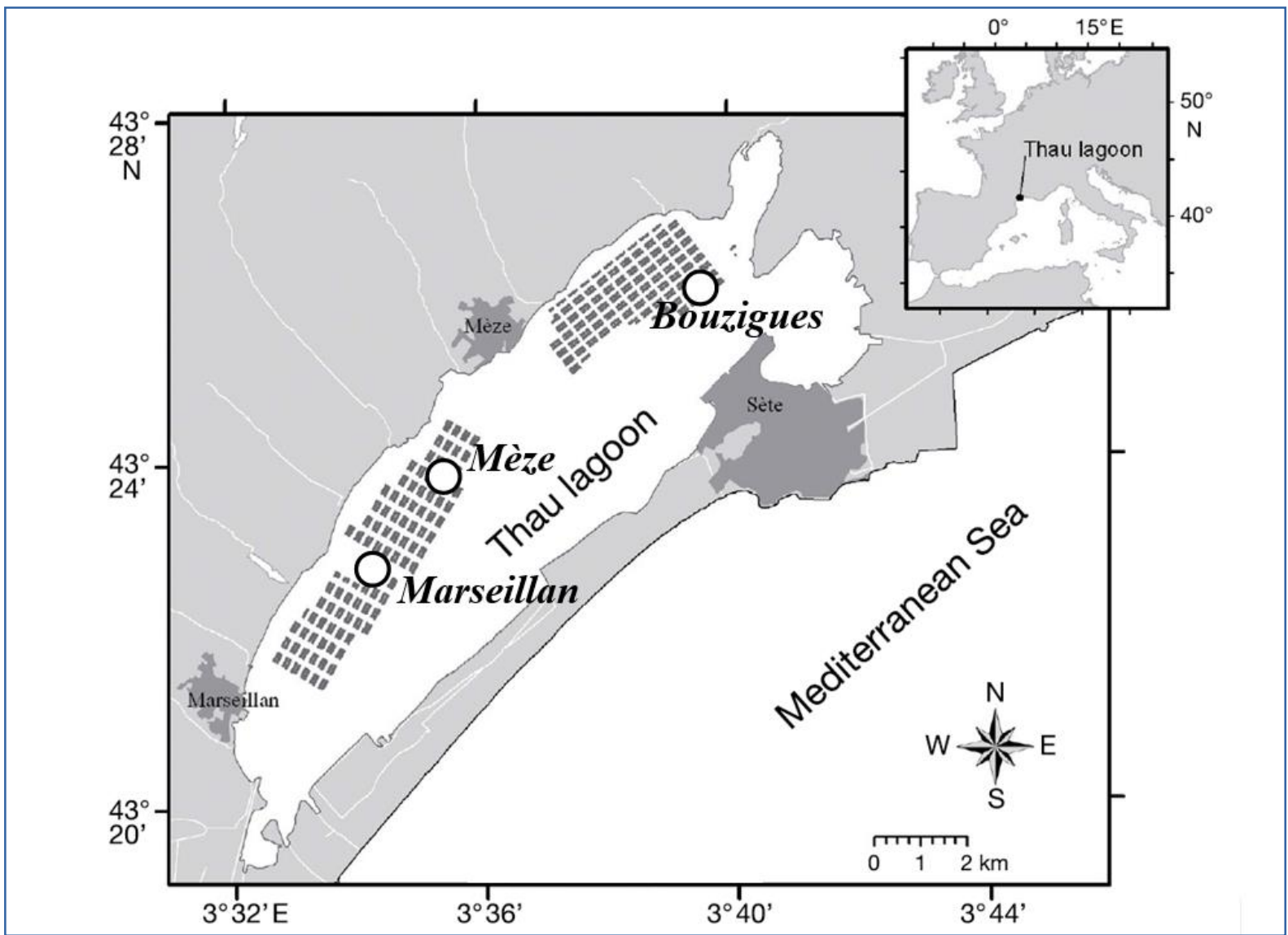

Fig. 1: The Mediterranean Thau lagoon with the location of the 3 sampled stations: oyster/larvae related collection and analyses were collected from the 3 sites, while environmental variables were recorded from the two extreme sites "Bouzigues" and "Marseillan". 
ACCEPTED MANUSCRIPT

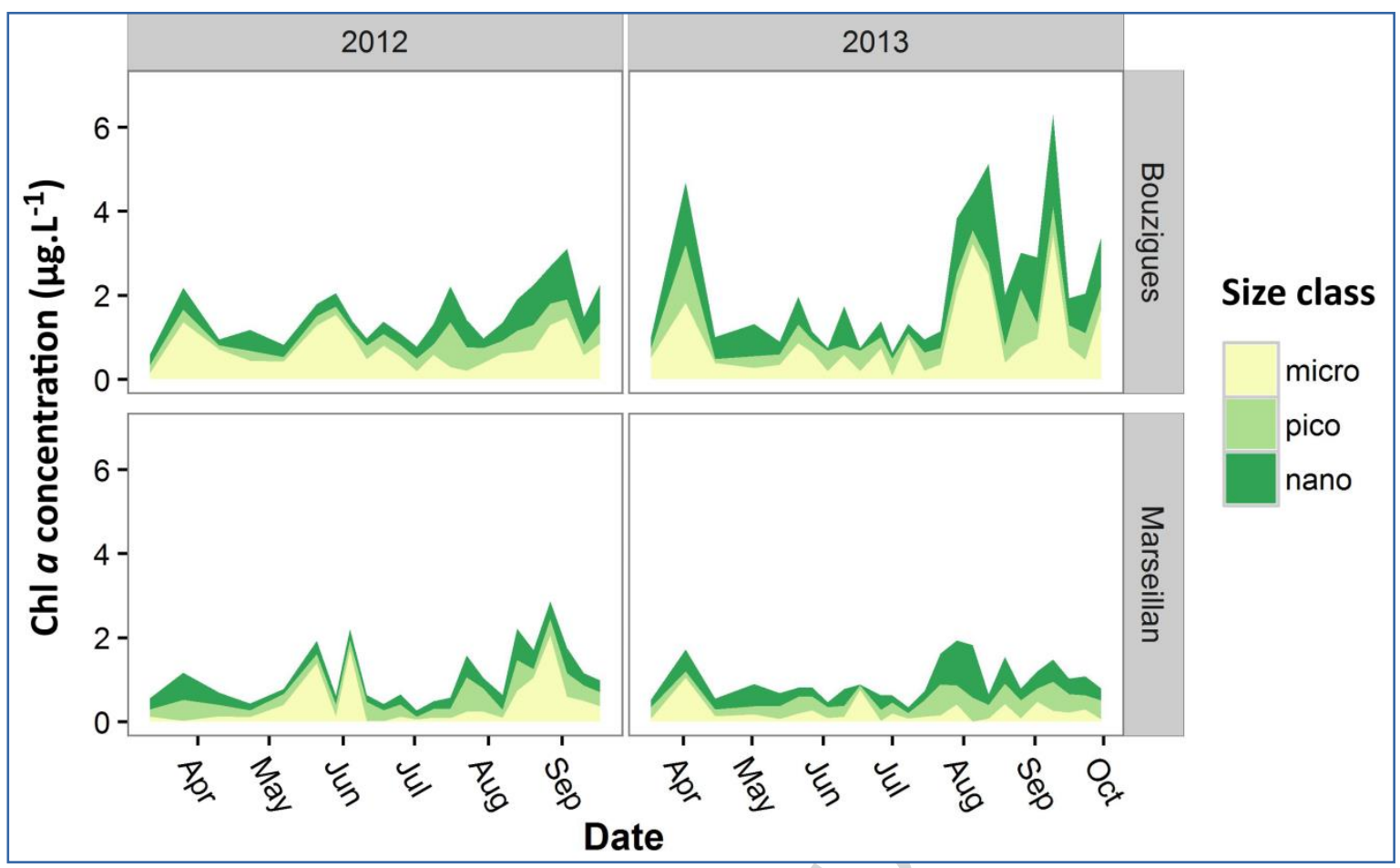

Figure 2: Relative ChI a concentration for the 3 size-class phytoplankton cells for both years 2012 and 2013 at the 2 stations Bouzigues and Marseillan. 


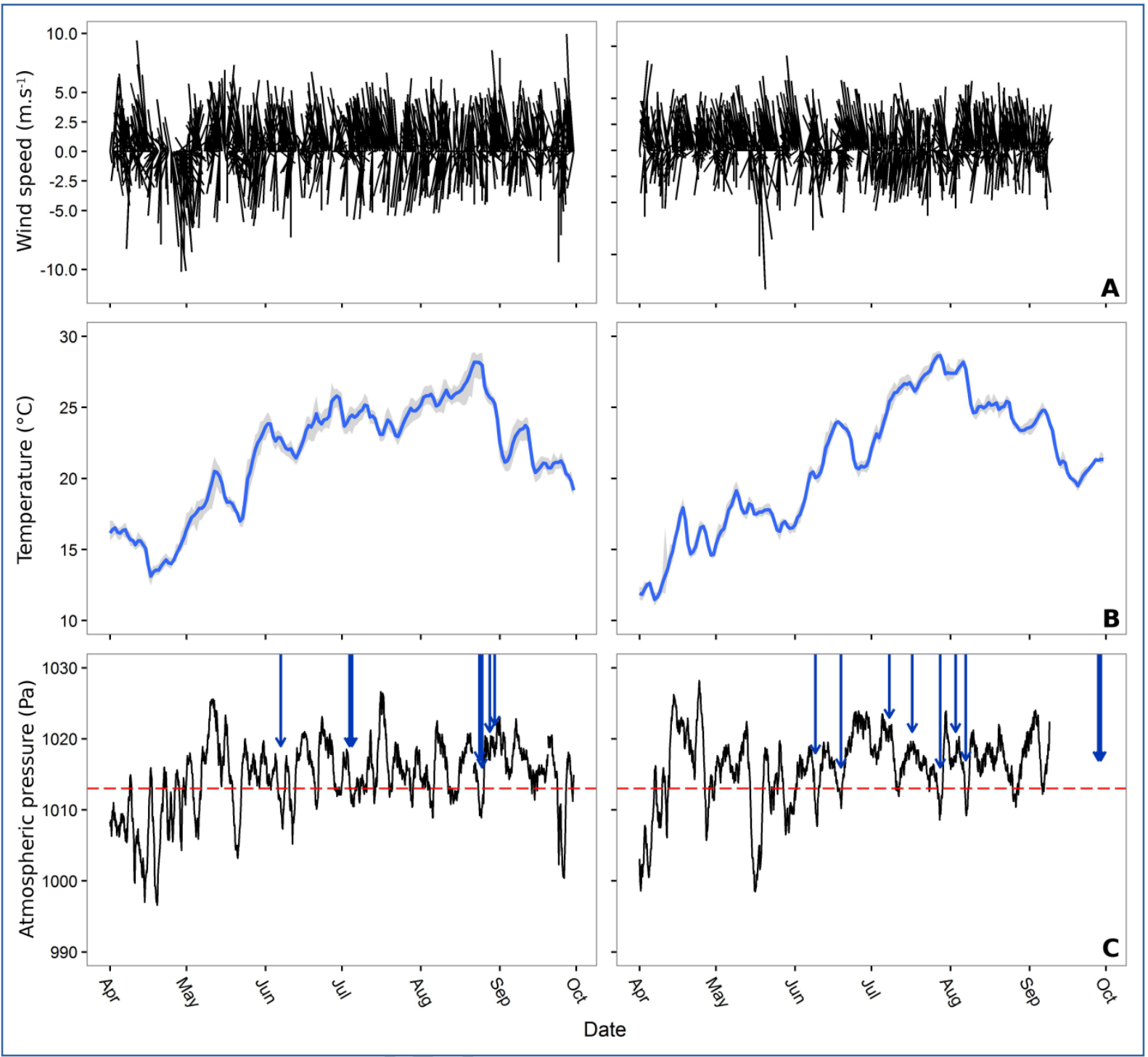

Figure 3: Wind velocities and direction (A), water temperature, averaged for the 3 sampled stations, min-max range being represented as a shadow area behind temperature (B), and atmospheric pressure at a $3 \mathrm{~h}$ resolution (C) for both years 2012 and 2013. Blue arrows represent lightening impacts on the Thau lagoon during thunderstorm events. Red dotted lines represent the bi-annual mean for both years 2012 and 2013. 


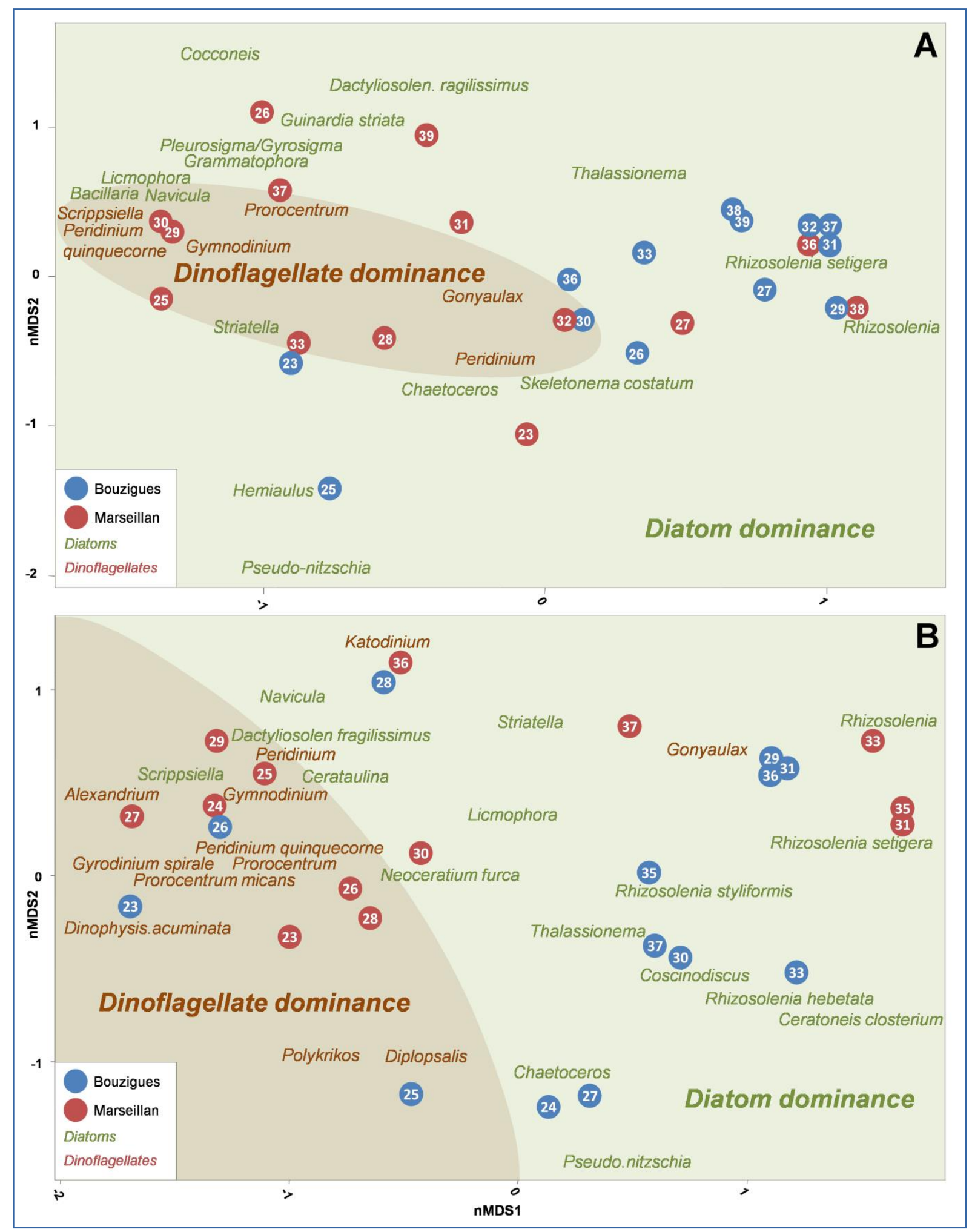

Figure 4: Non-metrical Multi Dimentional Scaling ( $n M D S$ ) analysis showing the relationship between summer samplings at the stations "Bouzigues" and "Marseillan" and phytoplankton species considered by biovolume in 2012 (A) and 2013 (B). Stress $=0.08$ for both analysis, $\mathrm{R}^{2}$ computation between ordination distance and observed dissimilarity $=0.97$ for 2012 and 0.98 for 2013. Species (genus labels) were considered in the analysis when they represented at least $4 \%$ of the total biovolume at a sampling date (numbers). 


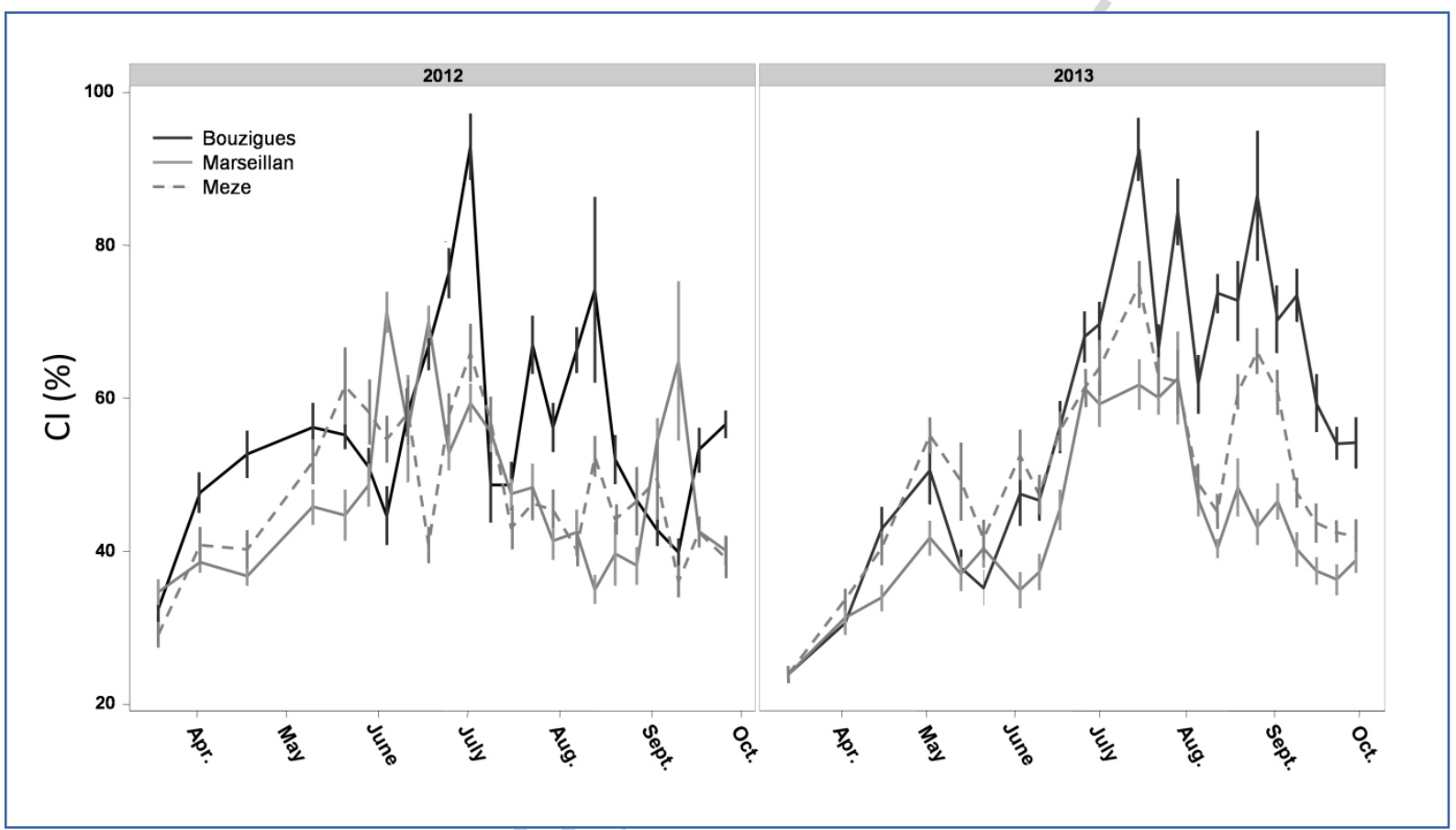

Figure 5: Condition index (CI) measured on C. gigas individuals for each sampling site in 2012 and $2013( \pm$ SE). 


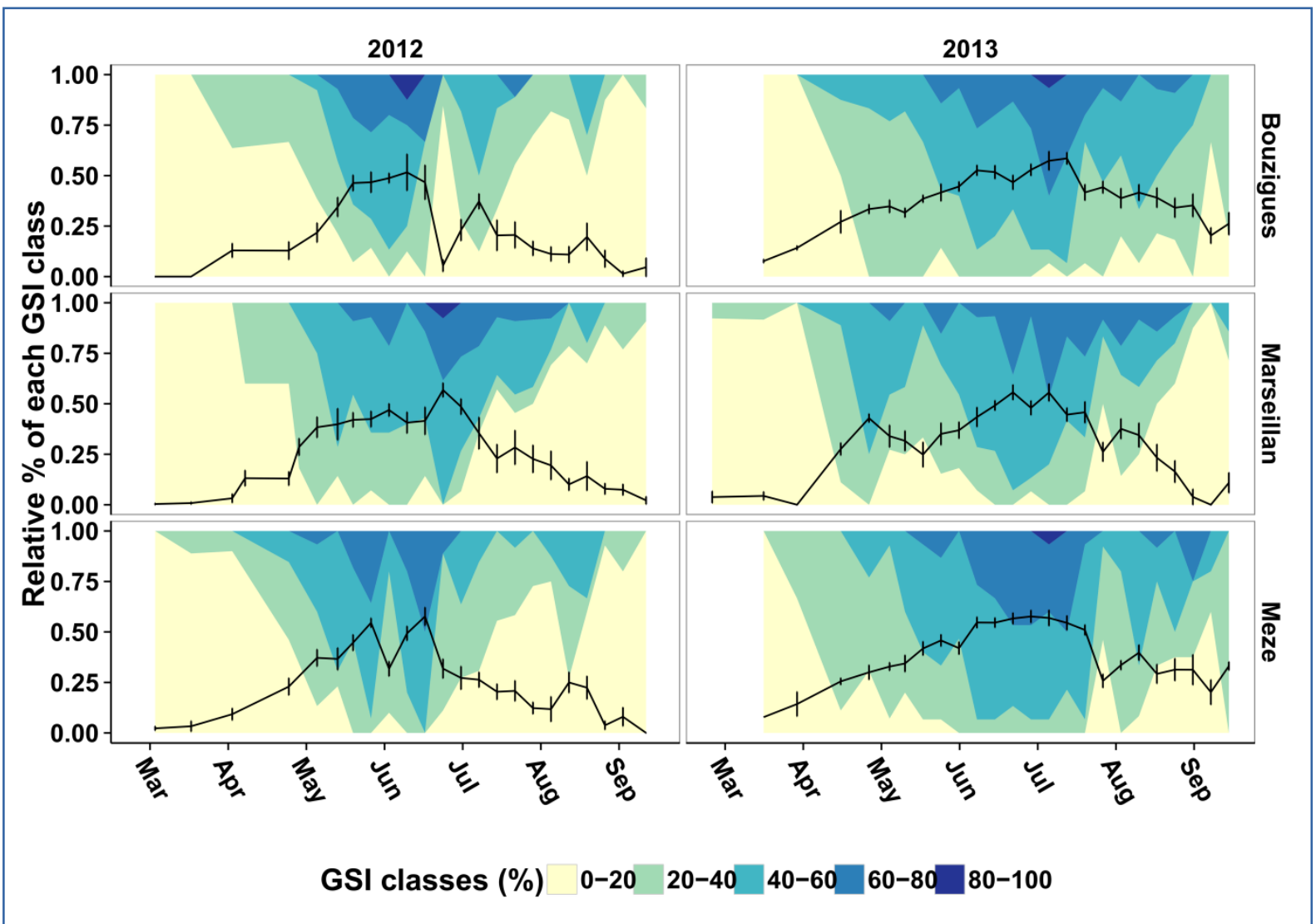

Figure 6: Relative contribution (\%) of C. gigas individuals to the gonado-somatic index class determined by quantitative histology for each sampling site in 2012 and 2013. The black line represents the mean GSI $( \pm$ SE). 


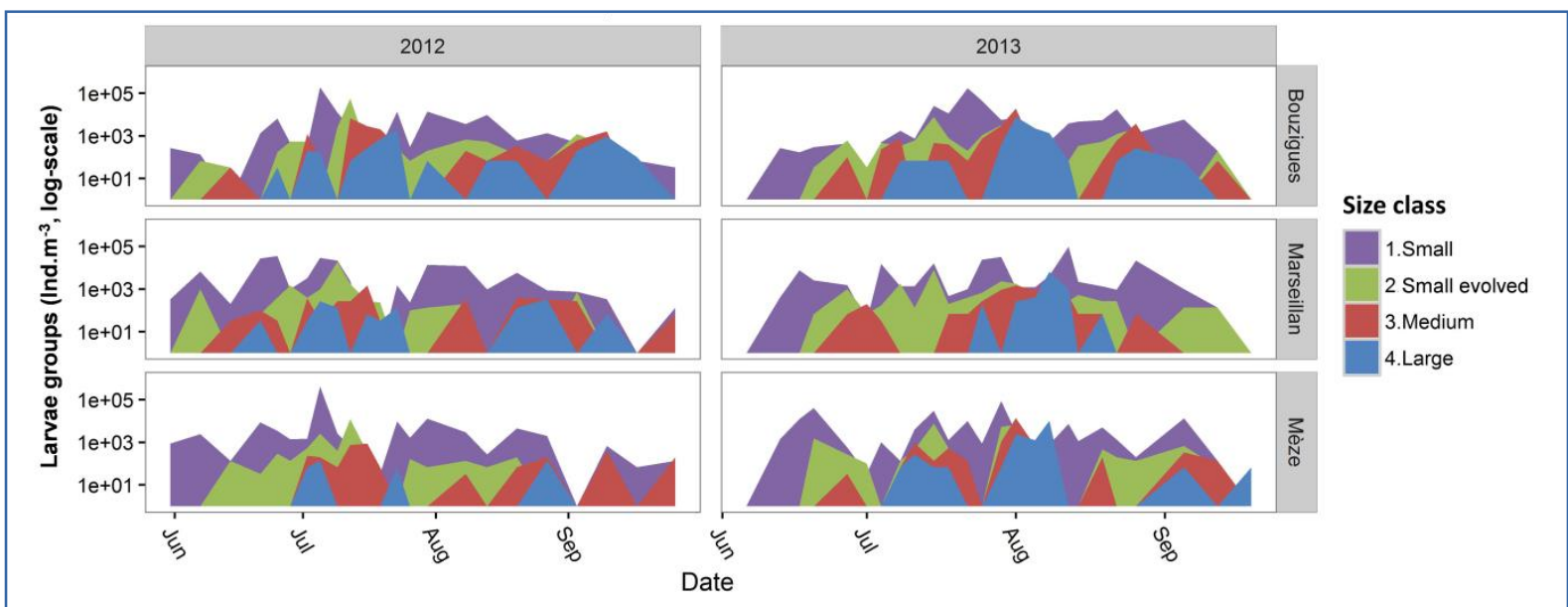

Figure 7: C. gigas larvae groups from water sampled within reproduction season for 2012 and 2013. The sampling weeks spread from mid-May to mid-October. Four stages of the larvae were differentiated during counting and are represented by colors: $\square=$ Small larvae, $\square=$ Small larvae evolved, $\square=$ Medium larvae, $\square=$ Large larvae. 


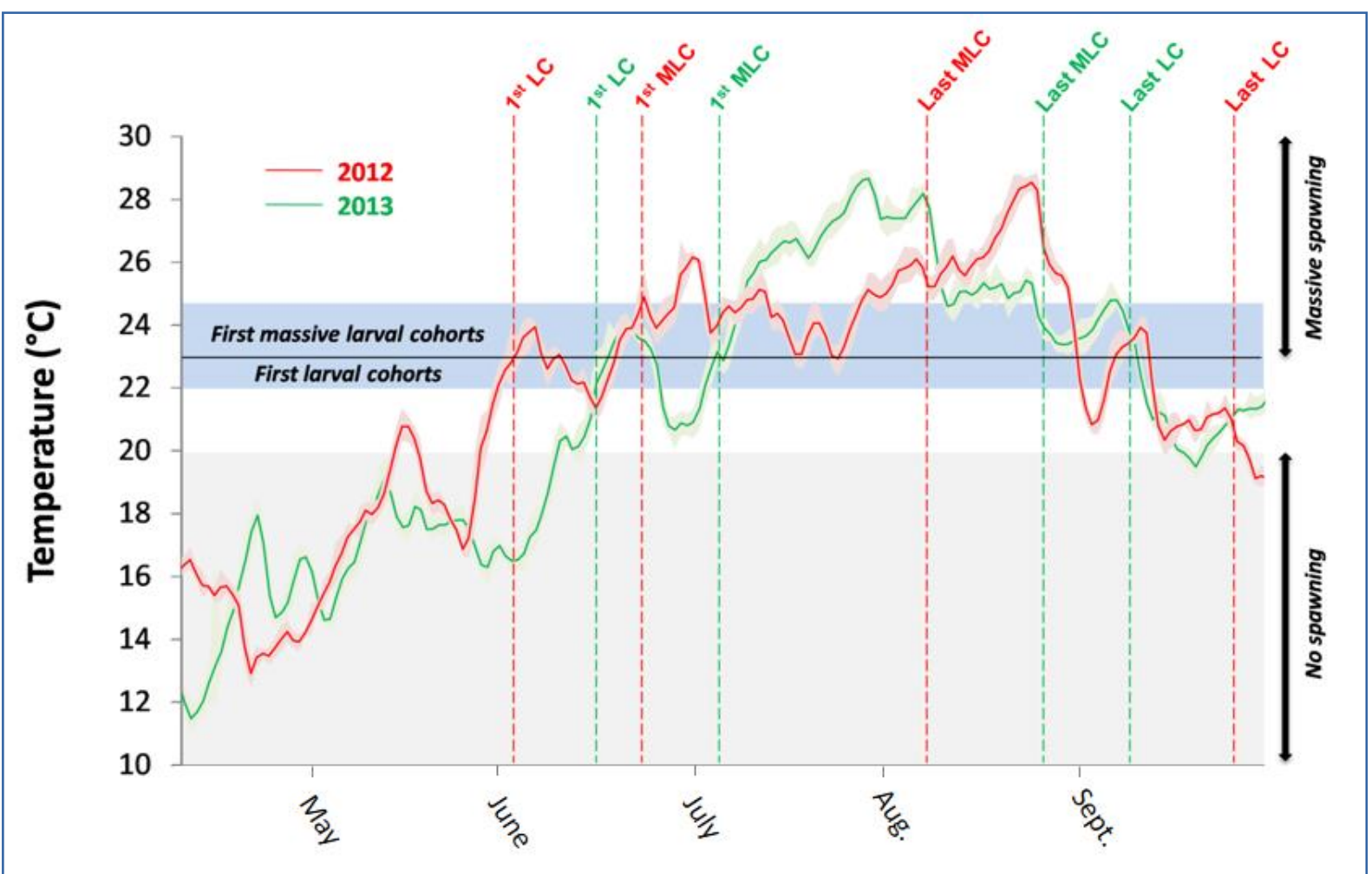

Figure 8: Relationship between temperatures and associated temperature daily ranges and small larvae cohorts for both years 2012 and 2013. Temperature curves represent the mean temperature observed between the 3 sampled stations Bouzigues, Mèze and Marseillan. Vertical dotted lines indicate first/last larvae cohorts $\left(1^{\text {st }} \mathrm{LC} / \mathrm{Last}\right.$ LC) and first/last massive larvae cohorts $\left(1^{\text {st }}\right.$ MLC/Last MLC) observed in the water column. 


\begin{tabular}{|c|c|c|c|c|}
\hline 2012 & Family & Species & Contribution (\%) & Cumulated sum \\
\hline & Diatoms & Rhizosolenia setigera & (58.4 & 58.44 \\
\hline & Dinoflagellates & Gonyaulax & 9.18 & 67.58 \\
\hline & Diatoms & "Skeletonema.costatum & 7.64 & 75.22 \\
\hline & Dinoflagellates & Peridinium & 4.31 & 79.53 \\
\hline & Diatoms & Rhizosolenia sp. & 1.73 & 81.26 \\
\hline & Diatoms & Pseudo-nitzschia & 1.48 & 82.74 \\
\hline & Dinoflagellates & "Hemiaulus & 1.35 & 84.09 \\
\hline & Diatoms & Thalassionema & 1.07 & 85.16 \\
\hline & Dinoflagellates & Gymnodinium & 0.95 & 86.11 \\
\hline & Dinoflagellates & Prorocentrum & 0.57 & 86.68 \\
\hline \multirow[t]{11}{*}{2013} & Family & Species & Contribution (\%) & Cumulated sum \\
\hline & Diatoms & Rhizosolenia setigera & 32.61 & 32.61 \\
\hline & Diatoms & Chaetoceros & 16.72 & 49.33 \\
\hline & Diatoms & Thalassionema & 8.48 & 57.81 \\
\hline & Dinoflagellates & Gonyaulax & 7.81 & 65.62 \\
\hline & Diatoms & Rhizosolenia hebetata & 4.39 & 70.01 \\
\hline & Dinoflagellates & Prorocentrum & 2.67 & 72.68 \\
\hline & Dinoflagellates & Gymnodinium & 2.37 & 75.05 \\
\hline & Dinoflagellates & Peridinium & 1.97 & 77.02 \\
\hline & Diatoms & Striatella & 1.75 & 78.77 \\
\hline & Dinoflagellates & Diplopsalis & 1.22 & 79.99 \\
\hline
\end{tabular}

Table 1: SIMPER analysis related to phytoplankton species contribution to the dissimilarity between the 2 stations "Bouzigues" and "Marseillan". Shaded lines are common to both years 2012 and 2013. 


\begin{tabular}{|c|c|c|c|c|c|c|c|}
\hline \multirow[t]{2}{*}{ Station } & \multirow{2}{*}{$\begin{array}{c}\text { Observed } \\
\text { larval cohorts }\end{array}$} & \multicolumn{3}{|c|}{2012} & \multicolumn{3}{|c|}{2013} \\
\hline & & Date & Ind. $\mathrm{m}^{-3}$ & Daily mean $\mathbf{T}^{\circ}$ & Date & Ind. $\mathrm{m}^{-3}$ & $\begin{array}{c}\text { Daily mean } \\
\mathbf{T}^{\circ}\end{array}$ \\
\hline \multirow[t]{3}{*}{ Bouzigues } & First & \multirow[t]{2}{*}{ 05/07 } & \multirow[t]{2}{*}{187766} & \multirow[t]{2}{*}{$23.82 \pm 0.33$} & $15 / 07$ & 25466 & $26.53 \pm 0.38$ \\
\hline & Biggest & & & & $22 / 07$ & 169000 & $27.19 \pm 0.33$ \\
\hline & Last & $30 / 07$ & 13533 & $24.47 \pm 0.25$ & $22 / 08$ & 17733 & $24.45 \pm 0.19$ \\
\hline \multirow[t]{3}{*}{ Mèze } & First & \multirow[t]{2}{*}{$05 / 07$} & \multirow[t]{2}{*}{414633} & \multirow[t]{2}{*}{$24.76 \pm 0.15$} & $17 / 06$ & 12333 & $23.48 \pm 0.39$ \\
\hline & Biggest & & & & $29 / 07$ & 86466 & $28.03 \pm 0.20$ \\
\hline & Last & $30 / 07$ & 12866 & $24.78 \pm 0.36$ & 05/09 & 13333 & $24.51 \pm 0.31$ \\
\hline \multirow[t]{3}{*}{ Marseillan } & First & $21 / 06$ & 27466 & $24.89 \pm 0.45$ & $04 / 07$ & 14933 & $22.86 \pm 0.28$ \\
\hline & Biggest & $25 / 06$ & 35900 & $24.36 \pm 0.35$ & $12 / 08$ & 97133 & $25.04 \pm 0.46$ \\
\hline & Last & 08/08 & 11933 & $25.24 \pm 0.29$ & $26 / 08$ & 21933 & $23.91 \pm 0.26$ \\
\hline
\end{tabular}

Table 2: Summary of the principal larvae cohort observations at the 3 sampled stations for the years 2012 and 2013. Daily temperatures are given as mean of the day \pm SD $(n=24)$. 


\begin{tabular}{|c|c|c|c|}
\hline Station & Year & $\begin{array}{c}\text { Biggest larvae cohort } \\
\text { date }\end{array}$ & $\begin{array}{c}\text { Thunderstorm } \\
\text { date }\end{array}$ \\
\hline \multirow{2}{*}{ Bouzigues } & 2012 & $05 / 07$ & $04 / 07(\mathrm{~d}-1)$ \\
\cline { 2 - 4 } & 2013 & $22 / 07$ & $18 / 07(\mathrm{~d}-4)$ \\
\hline \multirow{2}{*}{ Mèze } & 2012 & $05 / 07$ & $04 / 07(\mathrm{~d}-1)$ \\
\cline { 2 - 4 } & 2013 & $29 / 07$ & $28 / 07(\mathrm{~d}-1)$ \\
\hline \multirow{2}{*}{ Marseillan } & 2012 & $25 / 06$ & - \\
\cline { 2 - 4 } & & & $07 / 08(\mathrm{~d}-1)$ \\
\hline
\end{tabular}

Table 3: Relationship between largest small larvae cohorts observed in the water column and potentially related thunderstorm occurrences. The delay in days is indicated between brackets. 